\section{EL RADICALISMO RIOCUARTENSE: RENOVACIÓN PARTIDARIA, SECTORES CONSERVADORES Y FASCISMO EN LOS ANNOS TREINTA}

THE RADICALISM OF RÍO CUARTO:

PARTY RENOVATION, CONSERVATIVE SECTORS

AND FASCISM IN THE THIRTIES

REBECA CAMAÑ̃O •

Rebeca Camaño es becaria doctoral del CONICET con sede en el Centro de Investigaciones Históricas de la Universidad Nacional de Río Cuarto e investigadora

\section{Resumen}

Bajo el influjo de la renovación partidaria, en los años treinta los sectores tradicionales que hasta entonces habían dominado al radicalismo riocuartense fueron paulatinamente desplazados por la fracción sabattinista. En este proceso ocupó un rol importante la Juventud Radical como impulsora de la conformación de un frente único antifascista conjuntamente con demócratas, socialistas y comunistas que puso en evidencia y deslegitimó a aquellos radicales poco afectos a las instituciones liberales. Como respuesta a esto, y al progresivo relegamiento de los cargos partidarios y públicos, estos sectores buscaron nuevas estrategias para acceder al poder. Recurrieron entonces a prácticas que implicaron el quebranto de la disciplina partidaria y, finalmente, decidieron escindirse del radicalismo y conformar una nueva agrupación política. Consecuentemente, estos reacomodamientos no solamente provocaron cambios al interior del partido sino que además implicaron transformaciones en el escenario político riocuartense. del Centro de Estudios Avanzados de la Universidad Nacional de Córdoba.

e-mail: rcs_arg@hotmail.com

\section{Summary}

Under the influence of party renewal, in the thirties traditional sectors that had previously dominated the radicalism in Río Cuarto were gradually displaced by the fraction lead by Sabattini. In this process had an important role Radical Youth as a driving of the conformation of an anti-fascist front together with Democrats, Socialists and Communists which delegitimized those radical militants with a weak commitment with liberal institutions. In response to this, and their progressive relegation in party and public positions, these sectors sought new strategies to gain power. They resorted to practices that involved the breach of party discipline and finally decided to cleave from the radicalism and form a new political organization. Consequently, these rearrangements caused changes not only within the party but also transformations in the political scene of Río Cuarto. 